\title{
Cytotoxic, Trypanocidal Activities and Physicochemical Parameters of nor- $\beta$-Lapachone-based 1,2,3-Triazoles
}

\author{
Eufrânio N. da Silva Júnior, ${ }^{a}$ Maria Aline B. F. de Moura, ${ }^{b}$ Antonio V. Pinto, ${ }^{c}$ \\ Maria do Carmo F. R. Pinto, ${ }^{c}$ Maria Cecília B. V. de Souza, ${ }^{a}$ Ana J. Araújo, ${ }^{d}$ Claudia Pessoa, ${ }^{d}$ \\ Letícia V. Costa-Lotufo, ${ }^{d}$ Raquel C. Montenegro, ${ }^{d}$ Manoel Odorico de Moraes, ${ }^{d}$ \\ Vitor F. Ferreira ${ }^{*, a}$ and Marilia O. F. Goulart*,b
}

${ }^{a}$ Departamento de Química Orgânica, Instituto de Química, Universidade Federal Fluminense, Campus do Valonguinho, 24020-141 Niterói-RJ, Brazil

${ }^{b}$ Instituto de Química e Biotecnologia, Universidade Federal de Alagoas, Tabuleiro do Martins, 57072-970 Maceió-AL, Brazil

${ }^{c}$ Núcleo de Pesquisas de Produtos Naturais, Universidade Federal do Rio de Janeiro, Cidade Universitária, 21944-970 Rio de Janeiro-RJ, Brazil

${ }^{d}$ Departamento de Fisiologia e Farmacologia, Universidade Federal do Ceará, Campus do Porangabussu, 60430-270 Fortaleza-CE, Brazil

A atividade citotóxica de cinco derivados 1,2,3-triazólicos da nor- $\beta$-lapachona e do precursor azidonaftoquinona, foi avaliada contra seis linhagens de células neoplásicas: SF-295 (sistema nervoso central), HCT-8 (cólon), MDAMB-435 (melanoma), HL-60 (leucemia), PC-3 (próstata) e B-16 (melanoma murino). Valores de $\mathrm{IC}_{50}$ entre 0,43 e 9,48 $\mu \mathrm{M}$ foram obtidos. A 3-(4-(1-hidróxicicloexil)-1H-1,2,3-triazol-1-il)-2,2-dimetilnaftol[1,2-b]furan-4,5-dione apresentou-se altamente citotóxica contra MDAMB-435, com $\mathrm{IC}_{50}$ menor do que o encontrado para doxorubicina (controle positivo). Na tentativa de obter correlação entre parâmetros físico-químicos (potencial de redução e clog P) e atividade citotóxica, estudos eletroquímicos foram realizados em tampão acetato, $\mathrm{pH} 4,5$, em eletrodo de carbono vítreo, e valores de log $\mathrm{P}$ calculados (clog P). Apesar da ausência de interação estrutural conjugativa entre o sistema quinônico e o anel triazólico, observou-se a influência do anel heterocíclico no comportamento voltamétrico, com deslocamento anódico dos potenciais de redução. Não se verificou correlação entre os parâmetros eletroquímicos $\left(E \mathrm{p}_{\mathrm{Ic}}\right)$ e a atividade citotóxica. Por outro lado, a comparação de $E \mathrm{p}_{\mathrm{Ic}}$ com atividades tripanocidas, já descritas, reafirmou a tendência de maior atividade biológica para quinonas mais eletrofílicas $\left(>E \mathrm{p}_{\mathrm{IC}}\right)$. Apesar da ausência de correlação direta, foi possível verificar que clog $\mathrm{P}$ influencia a atividade citotóxica: quanto menor a lipofilia $(<\operatorname{clog} \mathrm{P})$, menor a citotoxicidade $\left(>\mathrm{IC}_{50}\right)$.

The cytotoxicities of five nor- $\beta$-lapachone-based 1,2,3-triazoles and the precursor azidonaphthoquinone were assayed against six neoplasic cancer cell lines: SF-295 (central nervous system), HCT-8 (colon), MDAMB-435 (melanoma), HL-60 (leukaemia), PC-3 (prostate) and B-16 (murine melanoma). $\mathrm{IC}_{50}$ values ranging from 0.43 to $9.48 \mu \mathrm{M}$ were obtained. 3-(4-(1-hydroxycyclohexyl)-1H-1,2,3-triazol-1yl)-2,2-dimethylnaphtho[1,2-b]furan-4,5-dione proved highly cytotoxic to MDAMB-435, with $\mathrm{IC}_{50}$ even lower than the one from doxorubicin (positive control). In an attempt to correlate physicochemical parameters (reduction potentials and calculated $\log \mathrm{P}$ ) with cytotoxic activity, electrochemical studies were conducted in acetate buffer, $\mathrm{pH} 4.5$, using a vitreous carbon electrode and calculated $\log \mathrm{P}$ values were obtained. Despite the absence of a structural conjugative interaction between the two systems (quinone and triazole), the heterocyclic group was found to influence the voltammetric behaviour, as indicated by anodic shifts in the reduction potentials. No correlation was found between $E \mathrm{p}_{\mathrm{Ic}}$ and cytotoxicity. In contrast, a comparison of $E \mathrm{p}_{\mathrm{Ic}}$ with previously reported trypanocidal activities reconfirmed the trend for higher activity coupled with better quinone electrophilicity $\left(>E \mathrm{p}_{\mathrm{Ic}}\right)$. A leading term in the correlation of cytoxicity, despite the absence of a linear correlation, was the calculated log P: the lower the lipophilicity, the lower the cytoxicity $\left(>\mathrm{IC}_{50}\right)$.

Keywords: lapachones, cytotoxicity, reduction potentials, clog P, naphthoquinone-triazoles, trypanocidal agents

*e-mail: mofg@qui.ufal.br; cegvito@vm.uff.br 


\section{Introduction}

Cancer is the second leading cause of death worldwide after cardiovascular diseases. The antitumor potential of quinones has been known for more than three decades, ever since the seminal studies conducted by the National Cancer Institute, NCI-USA, in which a number of synthetic and natural quinones were assayed and showed anticancer activity. ${ }^{1}$ Since then, interest in this subject has grown exponentially. ${ }^{2-6}$

Quinones play a major role as bioreductive drugs. Indeed, they are reactive oxygen species (ROS) enhancers and redox catalysts. ${ }^{6-11} \mathrm{~A}$ striking feature of quinone chemistry is the ease of reduction and therefore the ability to act as oxidizing or dehydrogenating agents, the driving force being the formation of a fully aromatic system. ${ }^{6-7,9,11}$ In this regard, quinones are known to play a pivotal role in energy metabolism and in many other key biochemical processes, mainly in chemotherapy, which uses redox cycling drugs. ${ }^{9}, 11$

The electrochemical properties of quinone compounds are obviously very important for their bioreductive activation to either the semiquinone or hydroquinone. ${ }^{9,11}$ There are several examples of correlations between electrochemical potentials and biological activities in this class of compounds. For example, a definite correlation has been found between redox potentials and the inhibitory effects of naphthoquinones on Epstein-Barr virus early antigen activation ${ }^{12-14}$ and their cytotoxicity. ${ }^{15,16}$ In other cases, this correlation has not been evinced. ${ }^{17,18}$

There are also several examples of quinone activity outside the field of cancer, ${ }^{19}$ e.g., in Chagas' disease, where a correlation has been found between trypanocidal activity and redox potential. ${ }^{9,11,20}$

Chagas' disease is a long-term debilitating disease caused by the flagellate protozoan Trypanosoma cruzi, which is mainly transmitted by triatomine insects or by blood transfusion. However, several routes of transmission that do not involve insect vectors have also been described, such as transmission via blood products or transplantation of infected organs, and vertical transmission. It is one of the most serious endemic parasitic diseases of Latin America, with a social and economic impact far outweighing the combined effects of other parasitic diseases..$^{21}$ At present, the number of people infected with Chagas' disease worldwide is estimated to be about 10-12 million. The process of urbanization in Latin America and migratory population movements from endemic countries have led to the disease being diagnosed in non-endemic areas. ${ }^{22}$

A special feature of T. cruzi is its unique sensitivity to the action of intracellular generators of $\mathrm{H}_{2} \mathrm{O}_{2}$. T. cruzi possesses an original redox defence system based upon trypanothione and trypanothione reductase, a NADPH-dependent flavoprotein, which regenerates trypanothione from its oxidised form (disulphide form). It lacks catalase and glutatione peroxidase and is therefore considerably more sensitive to $\mathrm{H}_{2} \mathrm{O}_{2}$-induced oxidative stress than its biological hosts. To date, Chagas' disease has defied all attempts to develop an efficient chemotherapy. ${ }^{21}$ Despite the recognition of the importance of redox cyclers as potent trypanocidal agents, few reports have shown a possible correlation between redox potentials of quinones and trypanocidal activities. ${ }^{20}$

Since the finding that lapachol (1b), a natural naphthoquinone, has antitumor activity against carcinoma Walker $256,{ }^{23}$ several structural modifications have been made ${ }^{24}$ in order to find compounds with new, enhanced or more selective biological activities. ${ }^{25-30} \mathrm{An}$ important naphthoquinone obtained from lapachol $(\mathbf{1 b})$ is $\beta$-lapachone $(\mathbf{2 b})^{9}$ (Figure 1), which is currently under multiple Phase II clinical trials. ${ }^{31}$

Nor- $\beta$-lapachone (2a) also has anticancer activity against SF-295 (central nervous system), MDAMB-435 (melanoma), and HL-60 (leukaemia) within the range of $0.3-1.75 \mu \mathrm{M} .{ }^{32}$ Our group recently demonstrated that the introduction of arylamine groups (Figurea 1,3) in the dihydrofuran ring of $\mathbf{2 a}$ enhanced the anticancer activity of this substance against six cancer cell lines with the $\mathrm{IC}_{50}$ below $1.5 \mu \mathrm{M} .^{32}$

1,2,3-Triazoles are an important class of compounds possessing a variety of biological activities, ${ }^{33}$ e.g., as antiplatelet agents ${ }^{34}$ as dopamine D2 receptor ligands related to schizophrenia, ${ }^{35}$ and as anticonvulsant, ${ }^{36}$ anti-inflammatory, ${ }^{37}$ anti-allergic, ${ }^{38-41}$ antiviral ${ }^{42-45}$ and antimicrobial agents. ${ }^{46-51}$
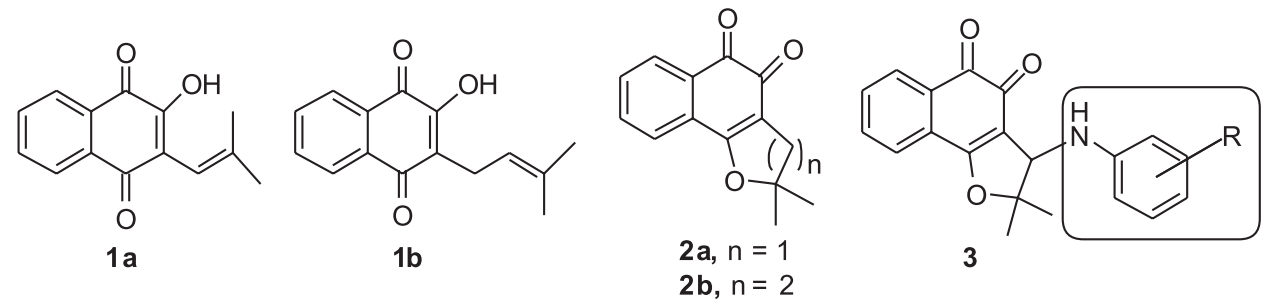

Figure 1. Some natural and semi-synthetic naphthoquinones endowed with anticancer activity. 
Since triazoles and naphthoquinones are important compounds with independent pharmacological activity, it would be relevant to produce some compounds by molecular hybridization using these moieties. The use of this approach in the design of new drugs has proved useful in modifying the selectivity profile and in reducing undesirable side effects. ${ }^{52}$ Additionally, this approach has proved successful for obtaining trypanocidal compounds (Scheme 1).$^{53}$ All synthesized naphthoquinoidal 1,2,3-triazoles proved more active than the original quinones against the infective bloodstream trypomastigote form of T. cruzi, with $\mathrm{IC}_{50}$ /day values in the range of 17 to $359 \mu \mathrm{M}$, the apolar phenyl substituted triazole 8 being the most active compound (Table 1). ${ }^{53}$

Based on an investigation of additional activities for this new class of compounds, this communication reports on the cytotoxic activities against six neoplasic cancer cell lines: SF-295 (central nervous system), HCT-8 (colon), MDAMB-435 (melanoma), HL-60 (leukaemia), PC-3 (prostate) and B-16 (murine melanoma) and against one normal cell, the murine fibroblast L-929, of azidoquinone 5 and of the naphthoquinones containing a 1,2,3-triazole ring in the C-3 position of the dihydrofuran ring of $\mathbf{2 a}$, named 6-10. An analysis was also made of their haemolytic activity, assayed with erythrocyte suspensions, in order to contribute to the clarification of the mechanism of biological action.
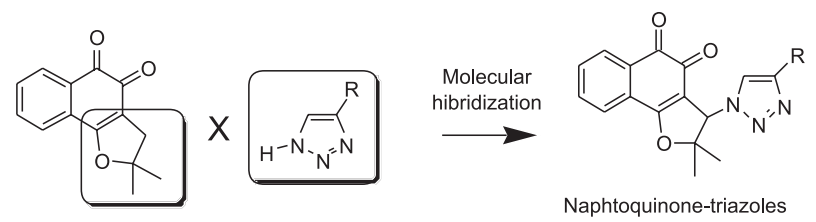

Scheme 1. Molecular hybridization for the synthesis of naphthoquinonetriazole moieties

Due to the importance of electrochemical studies of quinones in biological mechanisms of action, ,911 voltammetric parameters $\left(E \mathrm{p}_{\mathrm{Ic}}\right)$ are also presented, aiming to correlate biological and physicochemical parameters. The experiments were conducted in a protic medium (to resemble a hydrophilic environment). Additionally, based on the same rationale, ${ }^{9,11}$ previously reported data on trypanocidal activity ${ }^{53}$ are compared with measured reduction potentials.

Biological activity towards a live host involves a complex outcome that is not usually dominated by only one parameter. Generally, various physicochemical properties impact the pharmacokinetic and metabolic fate of a biologically active compound; hence, a thorough understanding of such characteristics is crucial in studies of modes of action. ${ }^{54} \mathrm{In}$

Table 1. Cytotoxic and trypanocidal activities expressed by $\mathrm{IC}_{50}$ in $\mu \mathrm{M}\left(\mu \mathrm{mol} \mathrm{L} \mathrm{L}^{-1}\right)$ of compounds $\mathbf{5 - 1 0}, \mathbf{2 a}, \mathbf{2} \mathbf{b}$ and doxorubicin (Doxo), with the respective confidence intervals. $\mathrm{Ep}_{\mathrm{Ic}}$ values in $\mathrm{V} v s$. $\mathrm{Ag} / \mathrm{AgCl}, \mathrm{Cl}^{-}$, aqueous (acetate buffer $\mathrm{pH} 4.5$ ), at $v=0.100 \mathrm{~V} \mathrm{~s}^{-1}$. Calculated $\log \mathrm{P}(\mathrm{clog} \mathrm{P})$

\begin{tabular}{|c|c|c|c|c|c|c|c|c|c|c|}
\hline Compd. & $\begin{array}{c}\text { HL-60 } \\
\mathrm{IC}_{50} /(\mu \mathrm{M})\end{array}$ & $\begin{array}{c}\text { MDAMB-435 } \\
\mathrm{IC}_{50} /(\mu \mathrm{M})\end{array}$ & $\begin{array}{c}\text { SF-295 } \\
\mathrm{IC}_{50} /(\mu \mathrm{M})\end{array}$ & $\begin{array}{c}\text { HCT-8 } \\
\mathrm{IC}_{50} /(\mu \mathrm{M})\end{array}$ & $\begin{array}{c}\text { PC-3 } \\
\mathrm{IC}_{50} /(\mu \mathrm{M})\end{array}$ & $\begin{array}{c}\text { B-16 } \\
\mathrm{IC}_{50} /(\mu \mathrm{M})\end{array}$ & $\begin{array}{c}\mathrm{L}-929 \\
\mathrm{IC}_{50} /(\mu \mathrm{M})\end{array}$ & $\begin{array}{c}\text { Trypanocidal } \\
\text { activity }^{\mathrm{b}}\end{array}$ & $\begin{array}{c}E \mathrm{p}_{\mathrm{Ic}} / \mathrm{V} \text { aqueous } \\
\Delta E \mathrm{p}_{\mathrm{Ic}}-E \mathrm{p}_{1 / 2}\end{array}$ & $\operatorname{clog} \mathrm{P}$ \\
\hline 5 & $\begin{array}{c}3.08 \\
1.48-6.46\end{array}$ & $\begin{array}{c}1.19 \\
1.08-1.34\end{array}$ & $\begin{array}{c}3.23 \\
2.38-4.38\end{array}$ & $\begin{array}{c}2.78 \\
2.26-3.38\end{array}$ & $\begin{array}{c}4.79 \\
4.31-5.35\end{array}$ & $\begin{array}{c}2.48 \\
\text { nd }\end{array}$ & $\begin{array}{c}3.30 \\
2.75-3.97\end{array}$ & $50.2 \pm 3.8$ & $\begin{array}{c}-0.176 \\
0.044\end{array}$ & 0.722 \\
\hline 6 & $\begin{array}{c}4.58 \\
3.42-6.11\end{array}$ & $\begin{array}{c}3.62 \\
\text { nd }\end{array}$ & $\begin{array}{c}4.75 \\
3.82-5.91\end{array}$ & $\begin{array}{c}5.97 \\
4.90-7.27\end{array}$ & $\begin{array}{c}7.84 \\
2.97-11.15\end{array}$ & $\begin{array}{c}2.80 \\
2.57-3.06\end{array}$ & $\begin{array}{c}9.48 \\
7.98-11.26\end{array}$ & $151.9 \pm 8.0$ & $\begin{array}{c}-0.165 \\
0.039\end{array}$ & 0.955 \\
\hline 7 & $\begin{array}{c}3.90 \\
\text { nd }\end{array}$ & $\begin{array}{c}4.24 \\
3.69-4.86\end{array}$ & $\begin{array}{c}5.53 \\
4.73-6.42\end{array}$ & $\begin{array}{c}8.11 \\
6.39-10.30\end{array}$ & $\begin{array}{c}8.88 \\
7.38-10.43\end{array}$ & $\begin{array}{c}3.38 \\
\text { nd }\end{array}$ & $\begin{array}{c}6.12 \\
5.35-7.01\end{array}$ & $348.1 \pm 44.2$ & $\begin{array}{c}-0.249 \\
0.037\end{array}$ & 0.419 \\
\hline 8 & $\begin{array}{c}2.10 \\
1.48-2.96\end{array}$ & $\begin{array}{c}1.21 \\
1.05-1.40\end{array}$ & $\begin{array}{c}2.53 \\
2.18-2.96\end{array}$ & $\begin{array}{c}3.18 \\
2.69-3.77\end{array}$ & $\begin{array}{c}2.58 \\
2.13-3.18\end{array}$ & $\begin{array}{c}1.56 \\
1.35-1.78\end{array}$ & $\begin{array}{c}2.42 \\
2.21-2.67\end{array}$ & $17.3 \pm 2.0$ & $\begin{array}{l}-0.163 \\
0.041\end{array}$ & 2.948 \\
\hline 9 & $\begin{array}{c}1.17 \\
0.99-1.37\end{array}$ & $\begin{array}{c}0.43 \\
0.36-0.51\end{array}$ & $\begin{array}{c}1.27 \\
1.12-1.42\end{array}$ & $\begin{array}{c}1.52 \\
1.37-1.73\end{array}$ & $\begin{array}{c}1.83 \\
1.58-2.16\end{array}$ & $\begin{array}{c}1.60 \\
\text { nd }\end{array}$ & $\begin{array}{c}2.85 \\
2.25-3.25\end{array}$ & $57.8 \pm 5.6$ & $\begin{array}{l}-0.155 \\
0.037\end{array}$ & 2.126 \\
\hline 10 & $\begin{array}{c}1.62 \\
1.25-2.05\end{array}$ & $\begin{array}{c}1.25 \\
1.15-1.39\end{array}$ & $\begin{array}{c}2.83 \\
2.40-3.31\end{array}$ & $\begin{array}{c}3.17 \\
2.67-3.73\end{array}$ & $\begin{array}{c}4.96 \\
4.35-5.65\end{array}$ & $\begin{array}{c}2.35 \\
2.29-3.09\end{array}$ & nd & nd & $\begin{array}{l}-0.165 \\
0.040\end{array}$ & 2.788 \\
\hline $2 a$ & $\begin{array}{c}1.75 \\
\text { nd }\end{array}$ & $\begin{array}{c}0.31 \\
0.22-0.39\end{array}$ & $\begin{array}{c}1.58 \\
1.31-1.88\end{array}$ & $\begin{array}{c}1.36 \\
1.18-1.53\end{array}$ & $\begin{array}{c}5.61 \\
4.74-6.67\end{array}$ & $\begin{array}{c}3.16 \\
\text { nd }\end{array}$ & nd & $>4800$ & $\begin{array}{l}-0.228 \\
0.037\end{array}$ & 1.240 \\
\hline $2 b$ & $\begin{array}{c}1.65 \\
1.49-1.90\end{array}$ & $\begin{array}{c}0.25 \\
0.16-0.33\end{array}$ & $\begin{array}{c}0.91 \\
0.74-1.11\end{array}$ & $\begin{array}{c}0.83 \\
0.74-0.87\end{array}$ & $\begin{array}{c}3.1 \\
2.68-3.59\end{array}$ & $\begin{array}{c}2.85 \\
2.68-3.06\end{array}$ & nd & $391.5 \pm 16.5$ & $\begin{array}{l}-0.244 \\
0.040\end{array}$ & 1.660 \\
\hline Doxo & $\begin{array}{c}0.04 \\
0.02-0.04\end{array}$ & $\begin{array}{c}0.86 \\
0.62-1.20\end{array}$ & $\begin{array}{c}0.42 \\
0.35-0.46\end{array}$ & $\begin{array}{c}0.07 \\
0.05-0.09\end{array}$ & $\begin{array}{c}0.44 \\
0.39-0.50\end{array}$ & $\begin{array}{c}0.05 \\
0.04-0.07\end{array}$ & nd & nd & nd & nd \\
\hline
\end{tabular}

a Data are presented as $\mathrm{IC}_{50}$ values and $95 \%$ confidence intervals obtained by nonlinear regression for all cell lines from three independent experiments. Doxorubicin was used as positive control. Data for $\mathbf{2 a}, \mathbf{2} \mathbf{b}$ and doxorubicin have already been published ${ }^{32}$ for all cell lines, except for PC-3 and B-16; ${ }^{\mathrm{b}}$ Activity of compounds against trypomastigote forms of $T$. cruzi $\left.\left[\mathrm{IC}_{50} / \mathrm{day} \mu \mathrm{mol} \mathrm{L} \mathrm{L}^{-1}\right)\right]^{53}$; nd: not determined. 
drug metabolism and pharmacokinetics, one of the most important parameters is lipophilicity, adequately described by experimentally obtained $\log \mathrm{P},{ }^{54}$ or by a calculated one $(\operatorname{cog} \mathrm{P})^{46}$; therefore, in the present case, we also report clog $\mathrm{P}$ for all the compounds.

\section{Results and Discussion}

\section{Chemistry}

The compounds were synthesized by the Huisgen reaction ${ }^{55}$ using copper catalysis. As shown in Scheme 2, the syntheses of 6-10 were carried out from the azidoquinone 5 by 1,3-dipolar cycloaddition. ${ }^{56}$ The 3-bromo-nor- $\beta$ lapachone (4), easily obtained from nor-lapachol (1a), ${ }^{57}$ is the precursor of $\mathbf{5}$, obtained so far by substitution with sodium azide. The synthesis and characterization of triazolic compounds $(\mathbf{6}-10)$ have already been reported, ${ }^{53}$ except for compound 10, whose spectroscopic data are included in the experimental section.

\section{Biology}

Compounds 5-10 were tested in vitro against six cancer cell lines and a normal murine fibroblast L-929, in comparison with the quinones $\mathbf{2 a}, \mathbf{2} \mathbf{b}$ and doxorubicin, the positive control, through an MTT assay. ${ }^{58}$ Concentrations that induce $50 \%$ inhibition of cell growth $\left(\mathrm{IC}_{50}\right)$ in $\mu \mathrm{M}$ are reported in Table 1. Based on their activity, the compounds were classified against at least two cancer cell lines as highly active $\left(\mathrm{IC}_{50}<2 \mu \mathrm{M}\right)$, moderately active $(2 \mu \mathrm{M}<$ $\left.\mathrm{IC}_{50}<10 \mu \mathrm{M}\right)$, or inactive $\left(\mathrm{IC}_{50}>10 \mu \mathrm{M}\right)$.

The great majority of the compounds are strongly or moderately cytotoxic against all cancer cell lines with $\mathrm{IC}_{50}$ in the range of 0.43 to $9.48 \mu \mathrm{M}$, although they are less cytotoxic than standards $\mathbf{2 a}, \mathbf{2} \mathbf{b}$ and doxorubicin, with few exceptions (see compound 9 , Table 1). The most sensitive cancer cell lines are MDAMB-435 and B-16, as already evidenced for $\mathbf{2 a}$, $2 \mathbf{b}$ and arylaminonaphthoquinones, ${ }^{32}$ unlike doxorubicin, which is more active against HL-60, HCT-8 and B-16. Compound 5 $\left(\mathrm{IC}_{50}=1.19 \mu \mathrm{M}\right)$ was selectively active against MDAMB-435. Among the triazolic naphthoquinones, compound $\mathbf{9}$ showed the highest activity against cancer cells $\left(\mathrm{IC}_{50}\right.$ ranging from 0.43 up to $1.83 \mu \mathrm{M}$ ) with the strongest activity against MDAMB-435. Additionally, it showed high selectivity compared with other cancer cells (2-4 $\times$ more selective) as well as towards normal cells $\left(\mathrm{L}-929, \mathrm{IC}_{50}=2.85 \mu \mathrm{M}\right)$ (Table 1$)$. The cytoxicity of compound 9 for melanoma cells is similar to that of the original quinones (2a and $\mathbf{2 b}$ ) and higher than doxorubicin. Towards HL-60, 9 is more active $\left(\mathrm{IC}_{50}=1.17 \mu \mathrm{M}\right)$ than the original quinones $\mathbf{2 a}$ and $\mathbf{2 b}$. Compound $\mathbf{8}$ showed higher cytotoxic activity than compounds $\mathbf{6}$ and $\mathbf{7}$. The presence of aromatic substituent (for 8 ) and non-aromatic ( 9 and $\mathbf{1 0}$ ) rings on the triazole moiety seems relevant for activity, possibly indicative of lipophilic effects. The absence of haemolytic activity $\left(\mathrm{EC}_{50}>508.35 \mu \mathrm{M}\right)$ suggests that the cytotoxicity of the compounds was not related to membrane damage of mouse erythrocytes.

\section{Electrochemistry and clog $P$}

The importance of the data on electron transfer involved in biological activities of quinones prompted us to conduct electrochemical studies of the majority of quinones, using cyclic voltammetry, in a protic (acetate buffer, $\mathrm{pH} 4.5$ ) medium. A relevant fact is that this paper offers the very first description of the electrochemistry of compounds $\mathbf{2 a}$ and $\mathbf{5 - 1 0}$.

In this study, we used the potential of the first reduction wave $\left(E \mathrm{p}_{\mathrm{Ic}}\right)$, which gives a quantitative measure of ease of reduction of an oxidant or electron acceptor, for purposes of comparison. Figures $2 \mathrm{~A}-\mathrm{D}$ display cyclic voltammograms (CV) of compounds 5, 2a, 6 and $\mathbf{9}$, respectively, as representatives of dihydrofuran naphthoquinones $(\mathbf{5}$, 2a) and triazolic quinones $(\mathbf{6}, 9)$, which are typical of
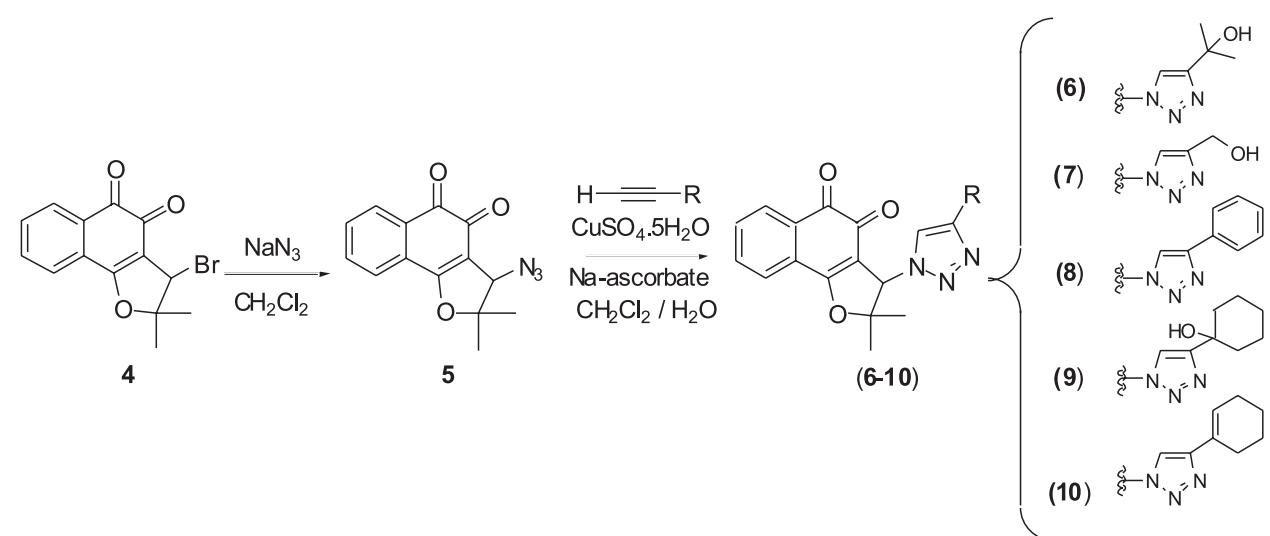
well-behaved quinones. The CVs show a reversible, diffusional and bielectronic pair of reduction waves $\left[\left(E \mathrm{p}_{\mathrm{Ic}}-\right.\right.$ $\left.\left.E \mathrm{p}_{1 / 2}\right)_{\text {experimental }}=37-44 \mathrm{mV},\left(E \mathrm{p}_{\mathrm{Ic}}-E \mathrm{p}_{1 / 2}\right)_{\text {theoretical }} \sim 30 \mathrm{mV}\right]$, leading to the formation of the respective hydroquinones, with participation of two protons. ${ }^{9,11}$

In this case, $E \mathrm{p}_{\mathrm{Ic}}$ values range from $-0.155 \mathrm{~V}$ (compound 9) up to $-0.249 \mathrm{~V}$ (compound 7) vs. $\mathrm{Ag} / \mathrm{AgCl}, \mathrm{Cl}^{-}$ $\left(0.1 \mathrm{~mol} \mathrm{~L}^{-1}\right)$, all the values representing easily reducible compounds. The ease of reduction in the series, expressed by $E \mathrm{p}_{\text {Ic }}$ (Table 1), is: $\mathbf{9}>\mathbf{1 0} \sim \mathbf{8} \sim \mathbf{6}>\mathbf{5}>\mathbf{2 a}>\mathbf{2 b} \sim \mathbf{7}$.

Despite absence of a structural conjugative interaction between the two systems (quinone and triazole) due to the presence of a spacer $\left(\mathrm{C}_{\mathrm{sp} 3}\right)$, the heterocyclic group influences the voltammetric behaviour, showing evidence of anodic shifts in the reduction potentials. This fact has been observed in several instances, e.g., the reduction of 2-methyl-5-nitroimidazole substituted at the $\mathrm{N}^{1}$-ethyl side chain with halogens. ${ }^{59}$ In the present case, it is possible that the electrogenerated hydroquinone is stabilized by hydrogen bonding with the heterocyclic nitrogen, which would favour reduction.

Although there is no direct correlation between these values and cytotoxicity, all the reduction potentials are in the region that allows the enzymatic reduction of quinones and further reaction with oxygen, explaining the presence of cytotoxicity for the great majority of assayed quinones. ${ }^{9,11}$ Banasri and coworkers ${ }^{18}$ also investigated the redox behaviour of aminoquinones and compared them with their cytotoxicity activities, but found no evidence of a correlation. Evidently the electrochemical parameters of quinonoids, albeit essential for cellular event analysis, do not always show a quantitative correlation with their cytotoxic properties. In fact, many other factors such as lipophilicity, membrane permeability, site-specific binding, etc., need critical consideration in order to rationalize the relationship of structural modulation and cytotoxicity. ${ }^{54}$

Log P values were calculated (Table 1 ) for all derivatives by semi-empirical methods. The values for the less cytotoxic compounds 5-7 were the lowest in the series. The more active compounds 8-10 showed the highest clog $\mathrm{P}$ values, even compared with references, $\mathbf{2 a}$ and $\mathbf{2 b}$. Partitioning can be related to either absorption or permeation. It is reasonable to suppose that those compounds can be better absorbed and permeated in the cell of the organism. As in the present case, the lipophilicity of catechols has been shown to enhance cytotoxicity. ${ }^{60}$ The lipophilicity of quinones is similar to that of the parent catechols. This means that the transport of both catechols and quinones into and out of the cell is similar, so there is no significant differentiation between reduced and oxidized forms with respect to transport through the cellular membrane. ${ }^{61}$
A

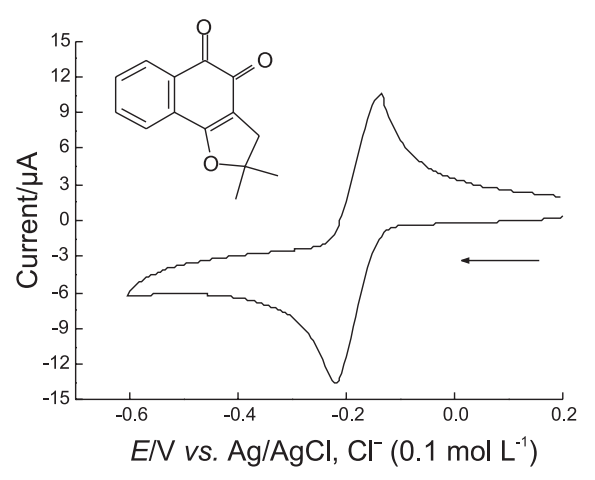

B

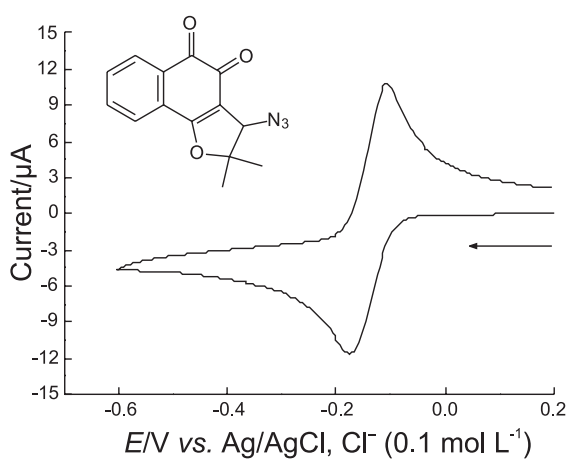

C
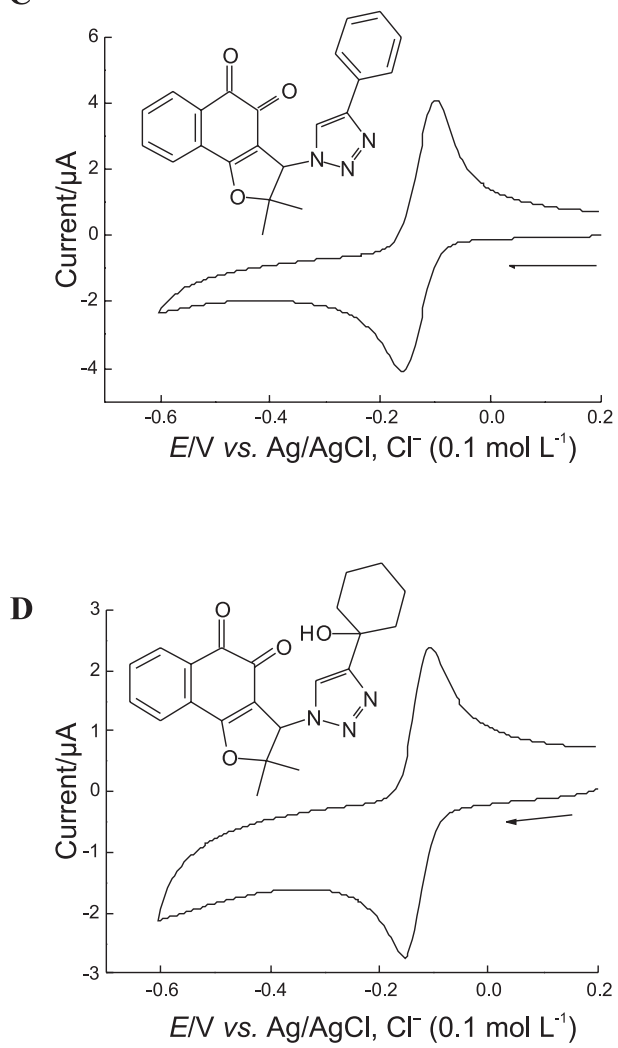

Figure 2. Cyclic voltammograms of naphthoquinones $\left(c=1 \mathrm{mmol} \mathrm{L}^{-1}\right)$ in buffered acetate solutions, $\mathrm{pH} 4.5$, vitreous carbon electrode, E/V vs. $\mathrm{Ag} / \mathrm{AgCl}, \mathrm{Cl}^{-}\left(0.1 \mathrm{~mol} \mathrm{~L}^{-1}\right)$. A: compound 2a, B: compound 5, C: compound 6 and D: compound 9. 
As mentioned in the introduction, it is worthy comparing electrochemical results and trypanocidal activities. $\mathrm{The}^{\mathrm{IC}} \mathrm{I}_{50}$ order shown in Table 1 is: $\mathbf{8}>\mathbf{5}>\mathbf{9}>\mathbf{6}>\mathbf{7}>\mathbf{2 b}>>\mathbf{2 a}$.

With regard to this activity, despite the impossibility of establishing a direct correlation due to the small number of compounds, it was observed that the more electrophilic compounds are better trypanocidal agents.

\section{Conclusions}

The nor- $\beta$-lapachone-based 1,2,3-triazoles were generally cytotoxic against the cancer cell lines tested, with $\mathrm{IC}_{50}$ below $5 \mu \mathrm{M}$. The results demonstrated that these triazoles are a promising addition to the arsenal of anticancer drugs. An enhancement of the activity between the triazole and 1,2-naphthoquinone moieties was demonstrated in the case of compound $\mathbf{9}$. The synthetic compounds 8-10 appear to be very interesting as new prototypes that could be exploited for the preparation of analogues, opening prospects for the development of new anticancer drugs, despite the fact that the two standard naphthoquinones, nor- $\beta$-lapachone and $\beta$-lapachone and doxorubicin were, generally, more potent. As for the calculated clog P values, the data (Table 1) allowed for the discrimination between highly and moderately cytotoxic compounds. Higher lipophilicity values (clog P) were associated with better cytotoxicity. Despite the importance of electrochemical data, in this case, no correlation was found between $E \mathrm{p}_{\mathrm{Ic}}$ and cytotoxicity. In contrast, the comparison of $E \mathrm{p}_{\mathrm{Ic}}$ with previously reported trypanocidal activities reconfirmed the trend for higher activity coupled with better quinone electrophilicity $\left(>E \mathrm{p}_{\mathrm{Ic}}\right)$.

\section{Experimental}

\section{Chemical synthesis}

Melting points were obtained on a Reichert micro hot stage and are uncorrected. Analytical grade solvents were used. The solvents were previously purified as described in the literature. ${ }^{62}$ Column chromatography was performed on silica gel (Acros Organics 0.035-0.070 mm, pore diameter about $6 \mathrm{~nm}$ ). Infrared spectra were recorded on a Perkin-Elmer FT-IR Spectrometer. ${ }^{1} \mathrm{H}$ and ${ }^{13} \mathrm{C}$ NMR were recorded at room temperature using a Varian Unity Plus 300 spectrometer, in the aforementioned solvents, with TMS as internal standard. Chemical shifts $(\delta)$ are given in ppm and coupling constants $(J)$ in hertz.

\section{Synthetic procedures}

Nor-lapachol (2-hydroxy-3-(2-methyl-propenyl)-[1,4]- naphthoquinone); $\beta$-lapachone (2,2-dimethyl-3,4-dihydro$2 \mathrm{H}$-benzo[h]chromene-5,6-dione) (2b); nor- $\beta$-lapachone (2,3-dihydro-2,2-dimethylnaphtho[1,2-b]furan-4,5-dione) (2a) and 3-bromo-nor- $\beta$-lapachone (3-bromo-2,3-dihydro2,2-dimethylnaphtho[1,2-b]furan-4,5-dione) (4), were prepared from lapachol $\mathbf{1 b}$ by standard procedures. ${ }^{63,57}$ The nor- $\beta$-lapachone-based 1,2,3-triazoles (6-10) were prepared from the azidoquinone (5), as described in the literature. ${ }^{53}$

3-(4-Cyclohex-1-enyl-1,2,3-triazol-1-yl)-2,2-dimethyl-2,3dihydro-naphtho[1,2-b]furan-4,5-dione (10)

The reaction of the 3-azido-2,2-dimethyl-2,3-dihydronaphtho[1,2-b]furan-4,5-dione (6) (299 mg, $1.1 \mathrm{mmol}$ ) in $13.4 \mathrm{~mL}$ of $\mathrm{CH}_{2} \mathrm{Cl}_{2} / \mathrm{H}_{2} \mathrm{O}$ (1:1), followed by the addition of $\mathrm{CuSO}_{4} \cdot 5 \mathrm{H}_{2} \mathrm{O}(12.5 \mathrm{mg}, 0.05 \mathrm{mmol})$, sodium ascorbate (29.5 mg, $0.14 \mathrm{mmol})$ and prop-2-in-1-ol (106 mg, $1 \mathrm{mmol}$ ) resulted in product $10,(345 \mathrm{mg}, 0.92 \mathrm{mmol}$, $92 \%$ yield) a yellow solid (mp 189-190 $\left.{ }^{\circ} \mathrm{C}\right) .{ }^{1} \mathrm{H}$ NMR $\left(300 \mathrm{MHz}, \mathrm{CDCl}_{3}\right) \delta: 8.18(1 \mathrm{H}, \mathrm{ddd}, J 7.3,1.7,0.6 \mathrm{~Hz})$, 7.82-7.71 (3H, m), $7.31(1 \mathrm{H}, \mathrm{s}), 5.95(1 \mathrm{H}, \mathrm{s}), 2.34-2.29$ $(2 \mathrm{H}, \mathrm{m}), 2.20-2.13(2 \mathrm{H}, \mathrm{m}), 1.75-1.62(5 \mathrm{H}, \mathrm{m}), 1.75(3 \mathrm{H}$, s), $1.20(3 \mathrm{H}, \mathrm{s}) ;{ }^{13} \mathrm{C} \mathrm{NMR}(75 \mathrm{MHz}$, DMSO-d 6 ) $\delta: 20.9$ $\left(\mathrm{CH}_{3}\right), 22.0\left(\mathrm{CH}_{2}\right), 22.2\left(\mathrm{CH}_{2}\right), 25.1\left(\mathrm{CH}_{2}\right), 26.1\left(\mathrm{CH}_{2}\right)$, $27.5\left(\mathrm{CH}_{3}\right), 66.5(\mathrm{CH}), 95.8\left(\mathrm{C}_{0}\right), 111.3\left(\mathrm{C}_{0}\right), 117.6(\mathrm{CH})$, $125.3(\mathrm{CH}), 125.3(\mathrm{CH}), 125.4(\mathrm{CH}), 126.6\left(\mathrm{C}_{0}\right), 126.8$ $\left(\mathrm{C}_{0}\right), 129.7(\mathrm{CH}), 131.4\left(\mathrm{C}_{0}\right), 133.1(\mathrm{CH}), 134.6(\mathrm{CH})$, $170.9\left(\mathrm{C}_{0}\right), 174.3(\mathrm{C}=\mathrm{O}), 179.9(\mathrm{C}=\mathrm{O})$; IR (film) $\mathrm{v}_{\max } / \mathrm{cm}^{-1}$ : $1656(\mathrm{C}=\mathrm{O}), 1620(\mathrm{C}=\mathrm{O})$.

\section{Anticancer assay}

Cytotoxicity against cancer cell lines: compounds 5-10 were tested for cytotoxic activity against six cancer cell lines in concentrations ranging from $25-18.57 \mu \mathrm{mol} \mathrm{L}^{-1}$ in the following cell lines SF-295 (central nervous system), HCT-8 (colon), MDAMB-435 (melanoma), HL-60 (leukaemia), PC-3 (prostate), B-16 (murine melanoma) and one normal cell L-929 (murine fibroblast), all supplied by the National Institute of Health, Bethesda, Maryland. All the cell lines were stored in RPMI 1640 medium supplemented with $10 \%$ fetal bovine serum, $2 \mathrm{~mol} \mathrm{~L}^{-1}$ glutamine, $100 \mathrm{U} / \mathrm{mL}$ penicillin and $100 \mu \mathrm{g} \mathrm{mL} \mathrm{m}^{-1}$ streptomycin at $37^{\circ} \mathrm{C}$ with $5 \% \mathrm{CO}_{2}$. Each compound was dissolved in DMSO and diluted with water to a concentration of $1 \mathrm{mg} \mathrm{mL}^{-1}$. They were then incubated with the cells for $72 \mathrm{~h}$. The negative control received the same amount of DMSO $(0.005 \%$ in the highest concentration). Doxorubicin $\left(17-1.0 \mu \mathrm{mol} \mathrm{L}^{-1}\right)$ was used as a positive control. The cell viability was determined by reduction of the yellow dye 3-(4,5-dimethyl-2-thiazol)2,5-diphenyl-2H-tetrazolium bromide (MTT) to a blue formazan product, as described by Mosmann. ${ }^{58}$ 


\section{Cell membrane disruption}

The tests were performed in 96-well plates using a $2 \%$ mouse erythrocyte suspension in $0.85 \% \mathrm{NaCl}$ containing $10 \mathrm{mmol} \mathrm{L}^{-1} \mathrm{CaCl}_{2}$, following the method described by Jimenez et al. ${ }^{64}$ The compounds diluted as mentioned above were tested at concentrations ranging from 1.5 to $200 \mu \mathrm{g} \mathrm{mL}^{-1}$. After $30 \mathrm{~min}$ of incubation at room temperature and centrifugation, the supernatant was removed and the released haemoglobin was measured spectrophotometrically at $540 \mathrm{~nm}$. DMSO was used as a negative control and Triton $\mathrm{X}-100(1 \%)$ was used as a positive control. After incubation at room temperature for $30 \mathrm{~min}$ and centrifugation, the supernatant was removed and the released haemoglobin was measured spectrophotometrically at $540 \mathrm{~nm} . \mathrm{ED}_{50}$ is the calculated dose that effectively induced lysis in $50 \%$ of the Triton X-100.

\section{Electrochemistry}

The electrochemical experiments of cyclic voltammetry (CV) were performed using an Autolab (Echo-Chemie, Utrecht, Netherlands) PGSTAT 20. The working electrode was a BAS (Bioanalytical Systems, West. Lafayette, IN, USA) GC electrode of $3 \mathrm{~mm}$ diameter, the counter electrode was a platinum coil, and the reference electrode was $\mathrm{Ag} \mid \mathrm{AgCl}, \mathrm{Cl}^{-}\left(0.1 \mathrm{~mol} \mathrm{~L}{ }^{-1}\right)$, and all were contained in a one-compartment electrochemical cell with $10 \mathrm{~mL}$ capacity. In the $\mathrm{CV}$ experiments, the scan rate varied from 0.020 to $2 \mathrm{~V} \mathrm{~s}^{-1}$, while the reported parameters were determined at a rate of $0.100 \mathrm{~V} \mathrm{~s}^{-1}$. It was necessary to degas the cell with a nitrogen flow for reduction studies. All the experiments were conducted at room temperature $\left(25 \pm 1^{\circ} \mathrm{C}\right)$.

Aqueous acetate buffer solutions $\left(0.2 \mathrm{~mol} \mathrm{~L}^{-1} ; \mathrm{pH} 4.5\right)$ were used in all the experiments and were prepared from analytical grade reagents and purified water (conductivity $<0.1 \mu \mathrm{S} \mathrm{cm}^{-1}$ ) obtained from a Millipore (Bedford, MA, USA) Milli-Q system. A Marconi (Piracicaba, Brazil) pHmeter with a combined glass electrode (model MAPA200; series 0113992) was used to measure the buffer $\mathrm{pH}$.

\section{Lipophilicity calculation (clog P)}

Theoretical parameters of lipophilicity (clog P) were calculated (Table 1) for all the derivatives using the semiempirical methods: AM1, using the Villar method included in the Spartan package, and OSIRIS Property Explorer (Thomas Sander, Actelion Pharmaceuticals Ltd) freely available on the web site http://www.organic-chemistry. org/prog/peo/. These programs were used to calculate the theoretical $\log \mathrm{P}$ based on the experimentally determined partition coefficients between $n$-octanol and water of commercially available drugs.

\section{Acknowledgments}

This work was supported by CNPq (National Research Council of Brazil), within the framework of the Instituto do Milênio/CNPq-INOFAR, MCT/CNPq/MS/Neoplasias, RENORBIO, BNB, as well as by CAPES, FAPERJ and FAPEAL (Brazil).

\section{Supplementary Information}

Available free of charge at http://jbcs.org.br, as PDF file.

\section{References}

1. Driscoll, J. S.; Cancer Chemother. Rep. 2 1974, 4, 3.

2. Pardee, A. B.; Li, Y-Z.; Li, C-J.; Curr. Cancer Drug Targets 2002, 2, 227.

3. Kongkathip, N.; Kongkathip, B.; Siripong, P.; Sangma, C.; Luangkamin, S.; Niyomdecha, M.; Pattanapa, S.; Piyaviriyagul, S.; Kongsaeree, P.; Bioorg. Med. Chem. 2003, 11, 3179.

4. da Silva Júnior, E. N.; de Souza, M. C. B. V.; Fernandes, M. C.; Menna-Barreto, R. F. S.; Pinto, A. V.; Pinto, M. C. F. R.; Lopes, F. A.; de Simone, C. A.; Andrade, C. K. Z.; Ferreira, V. F.; de Castro, S. L.; Bioorg. Med. Chem. 2008, 16, 5030.

5. da Silva, M. N.; Ferreira, V. F.; de Souza, M. C. B. V.; Quim. Nova 2003, 26, 407.

6. Asche, C.; Mini-Rev. Med. Chem. 2005, 5, 449.

7. Goulart, M. O. F.; Lima, N. M. F.; Santana, A. E. G.; Ferraz, P. A. L.; Cavalcanti, J. C. M.; Liwo, A.; Falkowsky, P.; Ossowsky, T.; J. Electroanal. Chem. 2004, 566, 25.

8. Monks, T. J.; Jones, D. C.; Curr. Drug Metab. 2002, 3, 425.

9. Hillard, E. A.; de Abreu, F. C.; Ferreira, D. C. M.; Jaouen, G.; Goulart, M. O. F.; Amatore, C.; Chem. Commun. 2008, 23, 2612.

10. Bolton, J. L.; Trush, M.; Penning, T.; Dryhurst, G.; Monks, T. J.; Chem. Res. Toxicol. 2000, 13, 135.

11. De Abreu, F. C.; Ferraz, P. A. M.; Goulart, M. O. F.; J. Braz. Chem. Soc. 2002, 13, 19.

12. Koyama, J.; Morita, I.; Kobayashi, N.; Osakai, T.; Cancer Lett. (Shannon, Irel.) 2004, 212, 1.

13. Koyama, J.; Morita, I.; Tagahara, K.; Osakai, T.; Hotta, H.; Yang, M. X.; Mukaianaka, T.; Nishino, H.; Tokuda, H.; Chem. Pharm. Bull. 2001, 49, 1214.

14. Koyama, J.; Morita, I.; Kobayashi, N.; Osakai, T.; Hotta, H.; Takayasu, J.; Nishino, H.; Tokuda, H.; Cancer Lett. (Shannon, Irel.) 2003, 201, 25. 
15. Crawford, P. W.; Gross, J.; Lawson, K.; Cheng, C. C.; Dong, Q.; Liu, D. F.; Luo, Y. L.; Szczepankiewicz, B. G.; Heathcock, C. H.; J. Electrochem. Soc. 1997, 144, 3710.

16. Pan, A-S.; Gonzalez, H.; Mol. Pharmacol. 1990, 37, 966.

17. Wu, H-Q.; Huang, Z-S.; Bu, X-Z.; Shen, Y-D.; Zhang, Z-L.; Xie, B-F.; Liu, Z-C.; Gu, L-Q.; Chan, A. S. C.; Eur. J. Med. Chem. 2005, 40, 1341.

18. Das Sarma, M.; Gosh, R.; Patra, A.; Hazra, B.; Eur. J. Med. Chem. 2008, 43, 1878.

19. Lima, N. M. F.; Correia, C. S.; Leon, L. L.; Machado, G. M. C.; Madeira, M. F.; Santana, A. E. G.; Goulart, M. O. F.; Mem. Inst. Oswaldo Cruz 2004, 99, 757.

20. Goulart, M. O. F.; Freitas, L. R.; Tonholo, J.; de Abreu, F. C.; Raslan, D. S.; Starling, S.; Zani, C. L.; Oliveira, A. B.; Chiari, E.; Bioorg. Med. Chem. Lett. 1997, 7, 2043.

21. Lockman, J. W.; Hamilton, A. D.; Curr. Med. Chem. 2005, 12, 945.

22. Gascón, J.; Albajar, P.; Cañas E.; Flores, M.; Prat J. G. I.; Herrera, R. N.; Lafuente, C. A.; Luciardi, H. L.; Moncayo, A.; Molina,L.; Muñoz, J.; Puente, S.; Sanz G.; Treviño, B.; SergioSalles, X.; Rev. Esp. Cardiol. 2007, 60, 285.

23. Rao, K. V.; McBride, T. J.; Oleson, J. J.; Cancer Res. 1968, 28 , 1952.

24. Neves-Pinto, C.; Dantas, A. P.; Moura, K. C. G.; Emery, F. S.; Polequevitch, P. F.; Pinto, M. C. F. R.; de Castro, S. L.; Pinto, A. V.; ArzneimForsch/DrugRes 2000, 50, 1120.

25. Pérez-Sacau, E.; Díaz-Peñate, R. G.; Estévez-Braun, A.; Ravelo, A. G.; Garcia-Castellano, J. M.; Pardo, L.; Campillo, M.; J. Med. Chem. 2007, 50, 696.

26. Ferreira, V. F.; Jorqueira, A.; Souza, A. M. T.; da Silva, M. N.; de Souza, M. C. B. V.; Gouvêa, R. M.; Rodrigues, C. R.; Pinto, A. V.; Castro, H. C.; Santos, D. O.; Araújo, H. P.; Bourguignon, S. C.; Bioorg. Med. Chem. 2006, 14, 5459.

27. Pinto, A. V.; Menna-Barreto, R. F. S.; de Castro, S. L.; Recent Progress in Medicinal Plants, Studium Press: Houston, 2006, v. 16, p. 109.

28. Neves-Pinto, C.; Malta, V. R. S.; Pinto, M. C. F. R.; Santos, R. H. A.; de Castro, S. L.; Pinto, A. V.; J. Med. Chem. 2002, 45, 2112.

29. Silva, R. S. F.; Costa, E. M.; Trindade, U. L. T.; Teixeira, D. V.; Pinto, M. C. F. R.; Santos, G. L.; Malta, V. R. S.; de Simone, C. A.; Pinto, A. V.; de Castro, S. L.; Eur. J. Med. Chem. 2006, 41, 526.

30. Barbosa, T. P.; Camara, C. A.; Silva, T. M. S.; Martins, R. M.; Pinto, A. C.; Vargas, M. D.; Bioorg. Med. Chem. 2005, 13, 6464.

31. Bey, E. A.; Bentle, M. S.; Reinicke, K. E.; Dong, Y.; Yang, C.-R.; Girard, L.; Minna, J. D.; Bornmann, W. G.; Gao, J.; Boothman, D. A.; Proc. Natl. Acad. Sci. USA 2007, 104, 11832.

32. Da Silva Júnior, E. N.; de Souza, M. C. B. V.; Pinto, A. V.; Pinto, M. C. F. R.; Goulart, M. O. F.; Pessoa, C.; Costa-Lotufo, L.; Montenegro, R. C.; Moraes, M. O.; Ferreira, V. F.; Bioorg. Med. Chem. 2007, 15, 7035.
33. Kacprzak, K.; Synlett 2005, 943.

34. Menegatti, R.; Cunha, A. C.; Ferreira, V. F.; Perreira, E. F. R.; El-Nabawi, A.; Eldefrawi, A.; Albuquerque, T. E. X.; Neves, G.; Rates, S. M. K.; Fraga, C. A. M.; Barreiro, E. J.; Bioorg. Med. Chem. 2003, 11, 4807.

35. Cunha, A. C.; Figueiredo, J. M.; Tributino, J.; Miranda, A. L.; Castro, H. C.; Zingali, R. B.; Fraga, C. A.; de Souza, M. C. B. V.; Ferreira, V. F.; Barreiro, E. J.; Bioorg. Med. Chem. 2003, 11, 2051.

36. Kelley, J. L.; Koble, C. S.; Davis, R. G.; McLean, E. W.; Soroko, F. E.; Cooper, B. R.; J. Med. Chem. 1995, 38, 4131.

37. Biagi, G.; Dell'Omodarme, G.; Ferretti, M.; Giorgi, I.; Livi, O.; Scartoni, V.; Il Farmaco 1990, 45, 1181.

38. Biagi, G.; Dell'Omodarme, G.; Ferretti, M.; Giorgi, I.; Livi, O.; Scartoni, V.; Il Farmaco 1992, 47, 335.

39. Biagi, G.; Ferretti, M.; Giorgi, I.; Livi, O.; Scartoni, V.; Lucacchini, A.; Il Farmaco 1993, 48, 1159.

40. Buckle, D. R.; Rockell, C. J.; Smith, H.; Spicer, B. A.; J. Med. Chem. 1984, 27, 223.

41. Buckle, D. R.; Rockell, C. J.; Smith, H.; Spicer, B. A.; J. Med. Chem. 1986, 29, 2262.

42. San-Felix, A.; Velazquez, S.; Perez-Perez, M. J.; Balzarini, J.; De, C. E.; Camarasa, M. J.; J. Med. Chem. 1994, 37, 453.

43. Velazquez, S.;Alvarez, R.; Perez, C.; Gago, F.; De, C. E.; Balzarini, J.; Camarasa, M. J.; Antivir. Chem. Chemother. 1998, 9, 481.

44. Al-Masoudi, N. A.; Al-Soud, Y. A.; Abdul-Zahra, A.; Heteroatom Chem. 2004, 15, 380.

45. Da Silva, F. C.; de Souza, M. C. B V.; Frugulhetti, I. I. P.; Castro, H. C.; Souza, S. L. O.; de Souza, T. M L.; Rodrigues, D. Q.; Souza, A. M. T.; Abreu, P. A.; Passamani, F.; Rodrigues, C. R.; Ferreira, V. F.; Eur. J. Med. Chem. 2009, 44, 373.

46. Costa, M. S.; Boechat, N.; Rangel, E. A.; da Silva, F. C.; de Souza, A. M. T.; Rodrigues, C. R.; Castro, H. C.; Júnior, N. I.; Lourenço, M. C. S.; Wardell, S. M. S. V.; Ferreira, V. F.; Bioorg. Med. Chem. 2006, 14, 8644.

47. Gallardo, H.; Conte, G.; Bryk, F.; Lourenço, M. C. S.; Costa, M. S.; Ferreira, V. F.; J. Braz. Chem. Soc. 2007, 18, 1285.

48. Holla, B. S.; Mahalinga, M.; Karthikeyan, M. S.; Poojary, B.; Akberali, P. M.; Kumari, N. S.; Eur. J. Med. Chem. 2005, 40, 1173.

49. Dabak, K.; Sezer, O.; Akar, A.; Anac, O.; Eur. J. Med. Chem. 2003, 38, 215.

50. Mares, D.; Romagnoli, C.; Andreotti, E.; Manfrini, M.; Vicentini, C. B.; J. Agric. Food Chem. 2004, 52, 2003.

51. Willner, D.; Jelenevsky, A. M.; Cheney, L. C.; J. Med. Chem. 1972, 15, 948.

52. Viegas-Junior, C.; Danuello, A.; da S. Bolzani, V.; Barreiro, E. J.; Fraga, C. A. M.; Curr. Med. Chem. 2007, 14, 1829.

53. da Silva Júnior, E. N.; Souza, M. C. B. V.; Pinto, A. V.; Pinto, M. C. F. R.; Ferreira, V. F.; Menna-Barreto, R. F. S.; Silva, R. S. F.; Teixeira, D. V.; de Simone, C. A.; de Castro, S. L.; Eur J. Med. Chem. 2008, 43, 1774. 
54. Van de Waterbeemd, H. V.; Gifford, E.; Nat. Rev. Drug Discovery 2003, 2, 192.

55. Huisgen, R. In 1,3-Dipolar Cycloaddition Chemistry; Padwa, A., ed., Wiley: New York, 1984.

56. Rostovtsev, V. V.; Green, G. L.; Fokin, V. V.; Sharpless, K. B.; Angew. Chem., Int. Ed. 2002, 41, 2596.

57. Pinto, A. V.; Pinto, M. C. F. R.; de Oliveira, C. G. T.; An. Acad. Bras. Cienc. 1982, 54, 107.

58. Mosmann, T.; J. Immunol. Methods 1983, 65, 55.

59. Cavalcanti, J. C. M.; de Abreu, F. C.; Oliveira, N. V.; de Moura, M. A. B. F.; Chaves, J. G.; Alves, R. J.; Bertinaria, M.; Fruttero, R.; Goulart. M. O. F.; Bioelectrochemistry 2004, 63, 353.
60. Lam, L. K.; Garg, P. K.; Swanson, S. M.; Pezzuto, J. M.; J. Pharm. Sci. 1988, 77, 393.

61. Chichirau, A.; Flueraru, M.; Chepeleva, L. L.; Wright, J. S.; Willmore, W. G.; Durst, T.; Hussain, H. H.; Charron, M.; Free Rad. Biol. Med. 2005, 38, 344.

62. Ferreira, V. F.; Quim. Nova 1992, 15, 348.

63. Fieser, L. F.; Fieser, M.; J. Am. Chem. Soc. 1948, 70, 3215.

64. Jimenez, P. C.; Fortier, S. C.; Lotufo, T. M. C.; Pessoa, C.; Moraes, M. E. A.; Moraes, M. O.; Costa-Lotufo, L. V.; J. Exp. Mar. Biol. Ecol. 2003, 287, 93.

Received: November 12, 2008 Web Release Date: April 3, 2009 


\section{Cytotoxic, Trypanocidal Activities and Physicochemical Parameters of nor- $\beta$-Lapachone-based 1,2,3-Triazoles}

Eufrânio N. da Silva Júnior, ${ }^{a}$ Maria Aline B. F. de Moura, ${ }^{b}$ Antonio V. Pinto, ${ }^{c}$ Maria do Carmo F. R. Pinto, ${ }^{c}$ Maria Cecília B. V. de Souza, ${ }^{a}$ Ana J. Araújo, ${ }^{d}$ Claudia Pessoa, ${ }^{d}$

Letícia V. Costa-Lotufo, ${ }^{d}$ Raquel C. Montenegro, ${ }^{d}$ Manoel Odorico de Moraes, ${ }^{d}$ Vitor F. Ferreira ${ }^{*, a}$ and Marilia O. F. Goulart*,b

${ }^{a}$ Departamento de Química Orgânica, Instituto de Química, Universidade Federal Fluminense, Campus do Valonguinho, 24020-141 Niterói-RJ, Brazil

${ }^{b}$ Instituto de Química e Biotecnologia, Universidade Federal de Alagoas, Tabuleiro do Martins, 57072-970 Maceió-AL, Brazil

${ }^{c}$ Núcleo de Pesquisas de Produtos Naturais, Universidade Federal do Rio de Janeiro,

Cidade Universitária, 21944-970 Rio de Janeiro-RJ, Brazil

${ }^{d}$ Departamento de Fisiologia e Farmacologia, Universidade Federal do Ceará,

Campus do Porangabussu, 60430-270 Fortaleza-CE, Brazil
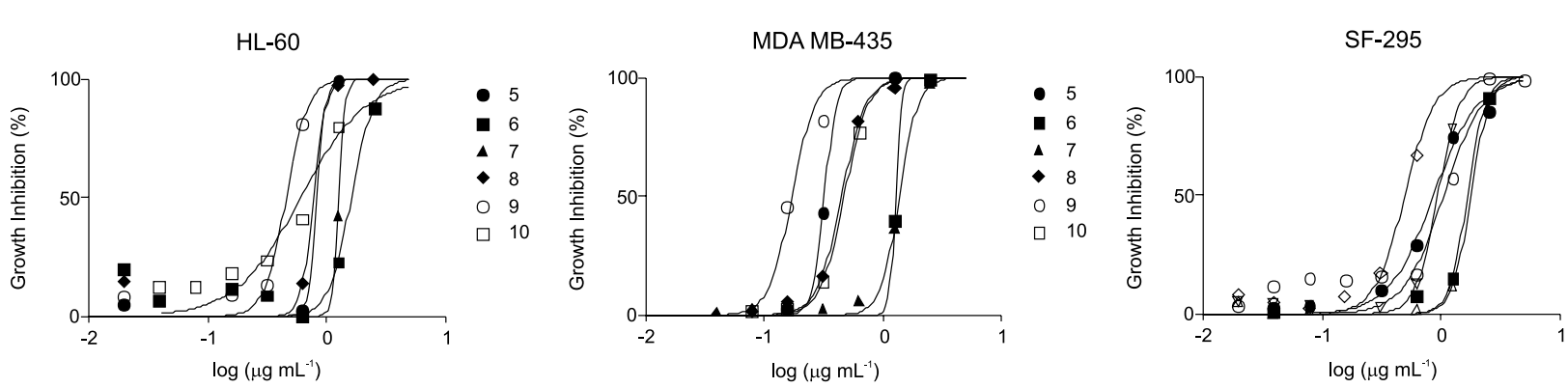

HCT-8

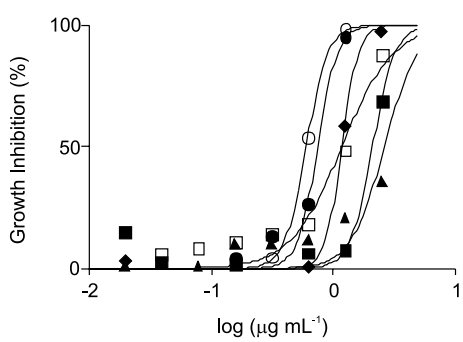

B 16

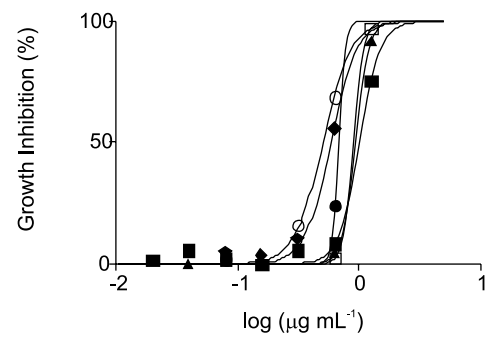

PC-3
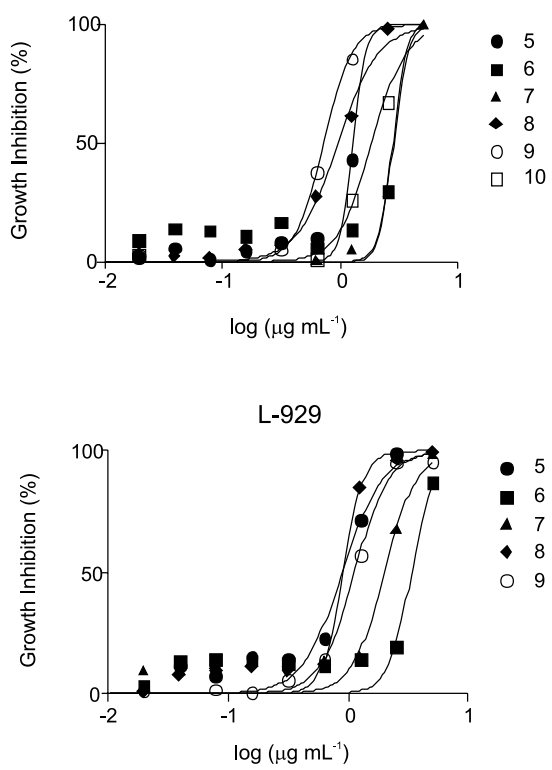

Figure S1. Plots of concentration vs response for $\mathrm{IC}_{50}$ for compounds 5-10 for each cell line

*e-mail: mofg@qui.ufal.br; cegvito@vm.uff.br 